\title{
ADDRESSING PRESENT CHALLENGES IN THE LIFE-CYCLE OF WETLANDS MANAGEMENT TO SUCCESSFULLY INTEGRATE SUSTAINABILITY AND GOOD GOVERNANCE
}

\author{
Judita TOMAŠKINOVÁ ${ }^{*}$, Ján TOMAŠKIN², Hubert THEUMA ${ }^{3}$, \\ Andrés F. ALCÁNTARA VALERO ${ }^{4}$, Vincent ATTARD ${ }^{3}$ \\ ${ }^{1}$ Institute of Applied Sciences, Malta College of Arts, Science \& Technology, Triq Kordin, PLA9032 Paola, Malta \\ ${ }^{2}$ Department of Environment, Faculty of Natural Science, Matej Bel University, Tajovskeho 40, \\ 97404 Banska Bystrica, Slovakia \\ ${ }^{3}$ Nature Trust-FEE Malta, Wied Gollieqa Environment Centre, Lower Level, Car Park 1, \\ University of Malta, Msida, Malta \\ ${ }^{4}$ Corporate Development Department, IUCN Center for Mediterranean Cooperation, Technological Park of \\ Andalusia. C. Marie Curie, 22. 29590, Campanillas, Malaga, Spain
}

Received 14 August 2020; accepted 27 October 2020

\section{Highlights}

- A gradation model of integrated protected area management, by carrying out an exhaustive assessment of the management effectiveness can be implemented in diverse categories of PA around Europe.

- The conceptual framework focusing on the interactive processes between social, cultural, ecological and economic subsystems is presented.

The development of protected areas towards sustainability requires new qualities, improved concepts and tools for new ways of planning.

D Protected area management transformation requires a wide range of skills and knowledge (including specific expertise) from modern interdisciplinary managers.

- The management process based on life-cycle assessment, proposing to reach the goal of five-dimensional sustainability in terms of regional development and good governance.

\begin{abstract}
The assessment of management effectiveness during the whole life-cycle process of protected areas (PAs) has become increasingly important, due to the lack of holistic background assessment work on management processes leading to a deeper knowledge of sustainable development (SD) principles. This paper aims to serve as a practical guide through a gradation model of integrated protected area management (IPAM) by carrying out an exhaustive trans-dimensional assessment of management effectiveness, identifying a critical field of activities and developing a framework mix of strategic recommendations leading to the implementation of an effective planning process. Our results could aid in the prioritisation of key decisions towards a more in-depth understanding of how to set up a balanced IPAM, as well as to enable managers and decision-makers to focus on activities that can further pre-established aims and reach the goal of five-dimensional sustainability in terms of SD and good governance.
\end{abstract}

Keywords: wetland, protected area, life-cycle assessment, governance, sustainability, participation.

\section{Introduction}

Wetlands are precious ecosystems covering roughly $6 \%$ of the planet's landmass (European Environment Agency, 2008; Smardon, 2015). They sustain an extensive array of plant and animal species, offering nature-based solutions to buffer climate change impacts as well as a broad range of public goods and services such as tourism and freshwater supply. Despite this, policy and decision-makers have been slow to recognise the worth of such habitats, leading to a diminution in environmental quality and of the abiotic diversity therein. Though wetland decline is a

${ }^{*}$ Corresponding author. E-mail: tomaskinova@gmail.com 
current global phenomenon - it is calculated that, in the 45 years leading up to 2015, our planet's wetlands have disappeared by an average of $35 \%$ - the Mediterranean region (Gokce, 2019; Ramsar Convention on Wetlands, 2018) has been particularly hard hit. Considering its status as one of the Earth's most dense biodiversity hotspots, in terms of both species diversity and number of endemites (Mittermeier et al., 2011), the staggering loss of $48 \%$ of all Mediterranean wetlands is indeed alarming (Ramsar Convention on Wetlands, 2018). There are a host of reasons for the deterioration and loss of these dynamic habitats (Geijzendorffer et al., 2019), which are so ecologically sensitive that they are affected by humaninflicted damage at three times the rate of forests (Gokce, 2019). However, the main agents appear to be inordinate land use and consequent degradation, urbanisation, pollution, (Cohen-Shacham et al., 2016; Geijzendorffer et al., 2019; Gokce, 2019; Tour Du Valat, 2020), climate change (Cramer et al., 2018; Ramírez et al., 2018) and invasive alien species (Mediterranean Wetland Observatory, 2018), all of which lead in turn to a reduction in biotic diversity. It is for the above reasons that a pressing need now exists to promote wetland conservation through wisely directed management actions, thus enabling them to retain their species diversity and productivity whilst enabling the sagacious use of the resources they possess. And such optimum and therefore sustainable usage of resources may only be arrived at by fully understanding and taking into account human usage - past and present - and its impact both at present and in the future (Gokce, 2019). In short, an efficient and effective management strategy may only be arrived at through comprehending the whole range of measures and actions required to conserve a site.

If the many global policy goals formulated in respect of sustainable development, conservation (Cirtina \& Gamaneci, 2015), the safeguarding and wise use of wetlands and the sustainment of biodiversity (IUCN, 2020a) and human well-being are to be achieved, including the relevant Sustainable Development Goals (SDGs) and the Aichi targets (Tomaskinova \& Tomaskin, 2018; Woodley et al., 2012), the various wetland stakeholders have to be identified and involved. All such stakeholders, linked to wetlands and therefore also together through the nature of their activities, will have to arrive at a common understanding, and the means to achieve this outcome is through the mechanism of the integrated management planning process (IUCN, 2020a; Woodley et al., 2012). These areas should be managed in a way that stimulates research and regional development while ensuring resource conservation and landscape protection. This considerable conceptual shift as regards the implementation of innovative approaches to improve protected areas (PAs) management effectiveness in the next decade implies a modern functional paradigm for protected areas (BorriniFeyerabend et al., 2013; Dudley, 2013; Ervin et al., 2010; IUCN, 2020b; Zawilińska, 2020). If carried out properly, such a process will deliver two outcomes, namely a plan for the wetland (Gokce, 2019) and, no less important, the empowerment of stakeholders and their engagement in strategic, informed management decisions and actions (Mediterranean Wetlands Initiative, 2018; Lange \& Jungmeier, 2014). The implementation of integrated policies and management is very often difficult to effect in coastal areas, where ecosystems and the challenges they harbour are more complex (Golumbeanu et al., 2019).

Current world policy targets are focused on the catalysation and support of efforts to broaden and effectively administer PAs so as to achieve the twin aims of i) halting biodiversity loss and ii) concurrently setting up nature reserves within the mainstream of natural solutions to current global challenges (Dudley et al., 2017), which include land deterioration, climate change (Gross et al., 2016), health and well-being, and food and water sufficiency (Dudley et al., 2016). In fact, according to Aichi Biodiversity Target 11, the global goal is to have at least $17 \%$ of terrestrial protected areas and $10 \%$ of marine protected areas effectively managed by 2020 (Convention on Biological Diversity, 2020). The Aichi Target 11 Dashboard shows a global scale coverage of $15 \%$ for terrestrial areas and $7 \%$ for marine areas. However, the percentage amounts for effectively managed areas are much less: $5 \%$ for terrestrial areas and $1 \%$ for marine areas (UNEP-WCMC, 2020a).

Therefore modern protected area (PA) management strategies have to take into account all five dimensions of sustainable development (ecological, social, cultural, economic and safety aspects) (Tomaškinová et al., 2019) by incorporating a broad spectrum of management policies such as ecological management, visitor management (Lange \& Jungmeier, 2014) and knowledge management through education and information systems and the generation of scientific knowledge (Getzner et al., 2012). The vulnerable ecosystems themselves, their visitors, and the PA management side of PAs encompass the full spectrum of property rights, relevant policies, decisions bodies and authorities (Jungmeier, 2014) which make up the governance system of protected areas. Therefore, assessment of PA management effectiveness may carry out a crucial role in a conceptual model of participative protected area management. This model has to be built simultaneously with efficient information management, because it must lead to a certain level of public support and a positive attitude vis-a-vis the protected area/s concerned. These should in turn provide the impetus for a different form of regional economic development which can then be a source of further funding for PA management (Getzner et al., 2012; Jungmeier, 2014; Lange \& Jungmeier, 2014). It is evident that a practical guide is required (Young et al., 2016) to assist managers and decision-makers in dealing with these challenging and demanding issues.

The necessity for coherent management of protected areas is most evident in countries like the Maltese Islands, which have lagged behind in this field. According to the Global Database on Protected Areas Management Effectiveness, up till August 2020 Malta had submitted no 
assessment of management effectiveness of such areas to UNEP-WCMC, whether by government entities or by non-governmental organizations (UNEP-WCMC, 2020b).

It is evident that a practical guide is required (Young et al., 2016) to assist managers and decision-makers in dealing with these challenging and demanding issues. Against this background, the aims of our study, based on the comprehensive assessment of management effectiveness of two coastal wetlands, were therefore: (i) to create a detailed management profile in the context of sustainable development dimensions and principles; (ii) to identify critical fields of activity based on PA life-cycle management, and (iii) to formulate present challenges and highpriority frame recommendations.

\section{Materials and methods}

The study was conducted from February to May 2020 in two coastal wetlands located in the Maltese Islands: Il-Ballut ta' Marsaxlokk (Il-Ballut) Nature Reserve, and L-Inhawi tal-Ghadira (Ghadira) Nature Reserve.

The choice of Malta was intentional since, as has been the case in the past, the small island environment allows researchers to study Malta as a testbed location in order to investigate the impact of developed technology and solutions for sustainability, with particular relevance for Southern European and Mediterranean countries. Within this context, green infrastructure was considered as critical for sustainable growth and social goals, which extend beyond the benefit of supporting biodiversity and acting as a catalyst for economic growth and improved human well-being. Efficient and effective PA management can provide important natural solutions for sustainability.

The featured PAs were purposely selected with regard to geographic location (the south-east and the north of Malta), land ownership and history of establishment. The wetland management set-ups which have been assessed are completely market-based and hence incorporate pertinent current activities and evident needs.

\subsection{Study area}

The Maltese Islands are a group of small islands (Malta, Gozo and Comino) situated in the Central Mediterranean Sea, $96 \mathrm{~km}$ south of Sicily and almost $300 \mathrm{~km}$ east of Tunisia, occupying an area of $316 \mathrm{~km}^{2}$. The size of the Maltese population has grown by 85,614 people and increased by $9.1297 \%$ since 2000 up to a total population of 475.701 in 1st January 2018 (Eurostat, 2020). For the year 2018, the population density of the Maltese Islands has been estimated at $1,514.469$ people per $\mathrm{km}^{2}$, which ranks Malta in the top ten of the World Statistics Database ( 8 rank) and 2nd in Europe (World Bank, 2020a). Due to its small size, as the smallest EU member state, it is particularly challenging for Malta to reconcile socio-economic demands and environmental requirements (Balzan et al., 2018).

In the Maltese Islands, the legal framework for protected area management is set up by various regulations issued almost exclusively under the main safeguarding law which is the Environment Protection Act (Chapter 549 of the Laws of Malta). Terrestrial protected areas have increased by $6.6 \%$ since 2016 , making up a total of $30.3 \%$ (World Bank, 2020b) of the total land area in 2017 (Figure 1), comprised in which total is $13.8 \%$ (more than $43.7 \mathrm{~km}^{2}$ ) made up of zones which are part of the EU Natura 2000 Network (ERA, 2018). Wetland areas, which are all coastal in nature, cover just $0.12 \%\left(0.39 \mathrm{~km}^{2}\right)$ of the Maltese Islands (Nature Trust - FEE Malta, 2020). They constitute a scarce habitat in Malta, sustaining specialised biota and playing a part in supplying regulation and maintenance services as well as cultural services (Malta Environment and Planning Authority, 2014; Energy \& Water Agency, 2020). Alteration of natural systems has been identified as constituting the most significant pressure on the Islands' biodiversity (ERA, 2018). The limited natural resources of the Islands have tended to exacerbate the effects of a varied spectrum of challenges, which are currently being faced due to factors such as a rapidly growing tourism sector, an accelerated spate of construction activity (which is further contributing to unsustainable levels of urbanisation), a general degradation of ecosystem services and a rapid increase in economic growth (Forzieri et al., 2017).

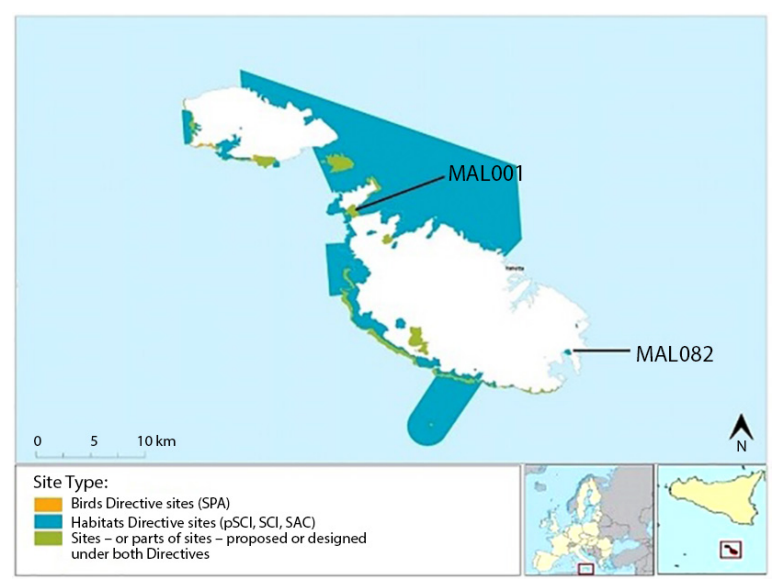

Figure 1. The territorial scope of of Natura 2000 sites (Bird and Habitats Directives) in Malta with locations of evaluated PAs. Adapted from: European Environment Agency (2018)

\subsubsection{Il-Ballut ta' Marsaxlokk Nature Reserve}

The saline wetland is located within the Mediterranean bio-geographical region and situated in the south-east of Malta. The Il-Ballut nature reserve (Figure 2, site location: long 14.552000; lat 35.840600) is considered to be of significant ecological and ornithological importance, and has been also confirmed as a site of Community importance (SCI) since 2008, and, as of December 2016, designated as a Special Area of Conservation (SAC), within the NATURA 2000 database (code MT0000014). It is one of the few remaining salt marshes (23.34 ha) in the Maltese Islands, protecting four habitat types listed in the Habitats Directive: Salicornia and other annuals colonising mud and sand (habitat type code 1310); Mediterranean salt 
meadows (Juncetalia maritimi) (habitat type code 1410); Mediterranean and thermo-Atlantic halophilous scrubs (Sacocornetea fructicose) (habitat type code 1420); and Southern riparian galleries and thickets (Nerio-Tamaricetea and Securinegion tinctoriae) (habitat type code 92D0). The Il-Ballut marshland represents one of the best Juncetalia maritimi communities of the Maltese Islands. A series of pools with brackish water are also found within the area. A number of species with a restricted distribution in the Maltese Islands are known from the area, including the endangered Carex extensa and the small Atriplex portulacoides (=Halimione portulacoides). (European Environment Agency, 2020a, 2020c; ERA, 2014a). Most of Il-Ballut ta' Marsaxlokk SAC is government land (ERA, 2014a).

\subsubsection{L-Inhawi tal-Ghadira Nature Reserve}

Ghadira Nature Reserve is a Ramsar site (No. 410, designation date: September 1988) (Ramsar Sites Information
Service, 2020, July 24) located in the north of Malta (Figure 3; site location: long 14.346300; lat 35.971300). Since April 2004 the nature reserve has been classified as a special protection area (SPA) and, as of March 2008, it has been confirmed as a SCI; furthermore, since December 2016 it has been designated as a SAC within the NATURA 2000 database (code MT0000015). This nature reserve (97.74 ha) comprises of brackish lake and salt marsh habitat, and protects 146 species listed in the Birds Directive and 7 habitat types listed in the Habitats Directive: Coastal lagoons (habitat type code 1150); Mediterranean salt meadows (Juncetalia maritimi) (habitat type code 1410); Mediterranean and thermo-Atlantic halophilous scrubs (Sarcocornetea fruticosi) (habitat type code 1420); Dunes with Euphorbia terracina (habitat type code 2220); Thermo-Mediterranean and pre-desert scrub (habitat type code 5330); West Mediterranean clifftop phryganas (Astragalo-Plantaginetum subulatae) (habitat type code 5410); and Pseudo-steppe with grasses and annuals of

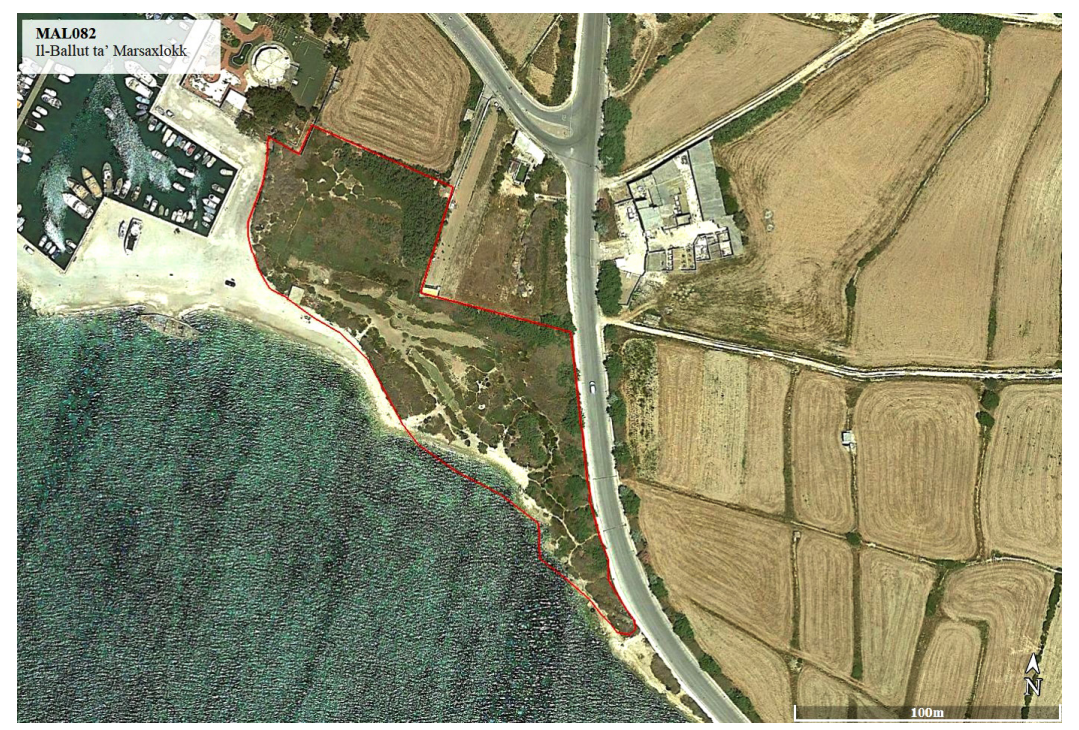

Figure 2. Il-Ballut ta’ Marsaxlokk Nature Reserve (MAL082) (source: Nature Trust - FEE Malta, 2020)

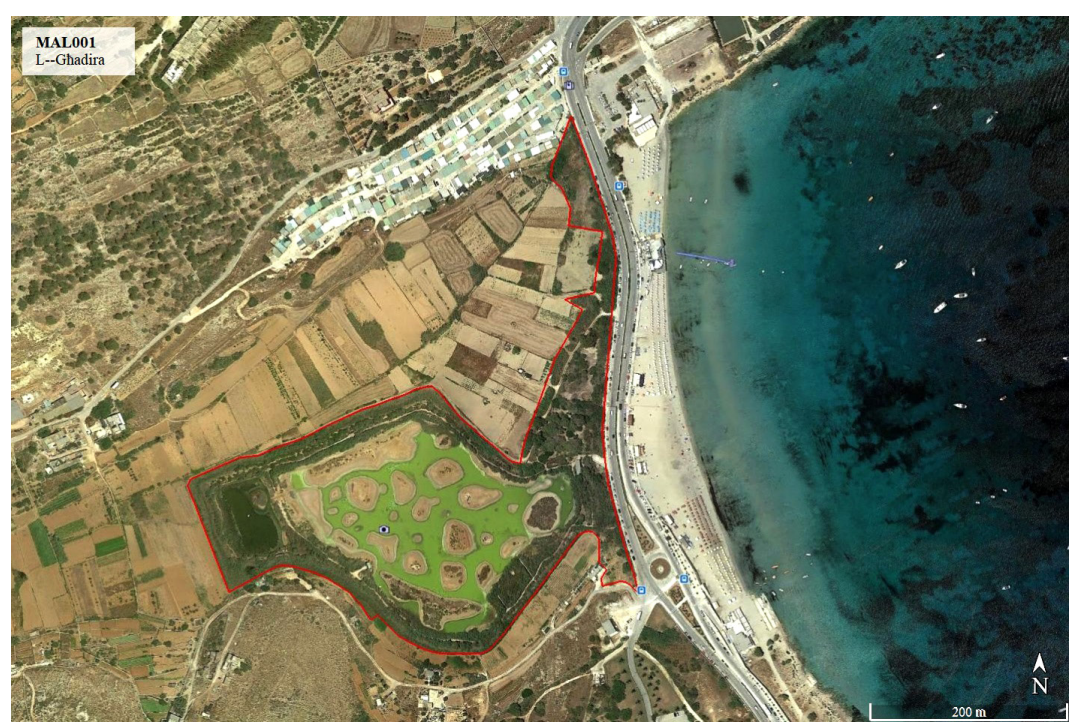

Figure 3. L-Inhawi tal-Ghadira Nature Reserve (MAL001) (source: Nature Trust - FEE Malta, 2020) 
the Thero-Brachypodietea (habitat type code 6220). (European Environment Agency, 2020b; ERA, 2014b). Most of Ghadira Nature Reserve is government land (ERA, 2014b).

\subsection{Protected area life-cycle assessment}

Using the methodology of integrative protected area management (IPAM toolbox), we have been evaluating the "life-cycle" of Il-Ballut and Ghadira according to five principal dimensions (Figure 4), ten key principles of sustainable development and 29 related "Fields of Activity" (FoA) within the five phases (Pre-phase, Basic Planning, Detailed Planning, Implementation and Networking) of IPAM (Table 1) (Getzner et al., 2012; Jungmeier, 2014; Lange \& Jungmeier, 2014; Tomaskinova \& Tomaskin, 2018; Tomaškinová et al., 2019). The third wave

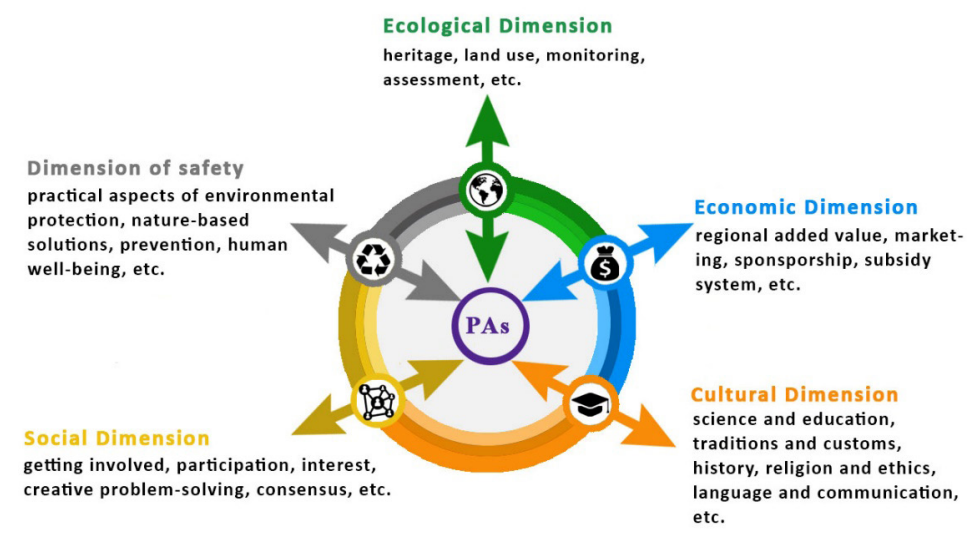

Figure 4. Five Dimensions Model of Sustainable Development (source: Authors' own draft)

Table 1. An overview of fields of activity in each phase of the life-cycle of protected areas according to IPAM toolbox (Getzner et al., 2012; Egner \& Jungmeier, 2014; Tomaškinová et al., 2019)

\begin{tabular}{|c|c|c|}
\hline \multicolumn{2}{|c|}{ Phases } & Fields of activity \\
\hline \multirow{4}{*}{\multicolumn{2}{|c|}{ Pre-phase }} & FoA-1 Development of idea and vision \\
\hline & & FoA-2 Feasibility check \\
\hline & & FoA-3 Communication and participation I \\
\hline & & FoA-4 Incorporation into PA-systems \\
\hline \multirow{9}{*}{ Planning phase } & \multirow{5}{*}{ Basic Planning } & FoA-5 Planning handbook \\
\hline & & FoA-6 Communication and participation II \\
\hline & & FoA-7 Basic investigation \\
\hline & & FoA-8 Implementation planning \\
\hline & & FoA-9 Designation and establishment \\
\hline & \multirow{4}{*}{ Detailed Planning } & FoA-10 Mission statement and basic concepts \\
\hline & & FoA-11 Ecosystem-based management plans \\
\hline & & FoA-12 Design of (regional) economic programs \\
\hline & & FoA-13 Specific planning (subsidiary plans) \\
\hline \multirow{12}{*}{ Implementation phase } & & FoA-14 Personnel and organizational development \\
\hline & & FoA-15 Evaluating management effectiveness \\
\hline & & FoA-16 Financing (business plan) \\
\hline & & FoA-17 Management assessment and limitation \\
\hline & & FoA-18 Data and information management \\
\hline & & FoA-19 Research setting and monitoring \\
\hline & & FoA-20 Communication and participation III \\
\hline & & FoA-21 Development of protected area's region \\
\hline & & FoA-22 Co-operation design \\
\hline & & FoA-23 Information, interpretation and education \\
\hline & & FoA-24 Visitor management, services and infrastructure \\
\hline & & FoA-25 Marketing and public relations \\
\hline \multirow{4}{*}{ Networking } & & FoA-26 Networking general \\
\hline & & FoA-27 Networking Economic \\
\hline & & FoA-28 Networking Social \\
\hline & & FoA-29 Networking Ecological \\
\hline
\end{tabular}


of civilisation associated with the information and knowledge phenomenon implies new models of management and a completely new philosophy (principles, paradigm) of management, as a multidisciplinary paradigm. The new "five dimensions concept" of PA management (Figure 4) is focussed on new approaches to protecting and creating benefits while taking into account the requirements of all stakeholders. This governance model, along with high stakeholder participation, leads to sustainable development of economic and social opportunities and benefits for all collaborators in ensuring the protection of the natural heritage with its associated ecosystem services and cultural values, and is based on five dimensions (Ecological, Economic, Cultural, Social and Safety). The IPAM expert system creates a draft questionnaire (94 questions) based on the created profile of the protected area which is under evaluation. Each of the questions contained therein allows respondent input according to a 3 -scale evaluation system (not yet started - started - finished) that provides input data for the processing software being used. The toolbox then gives a reading of the degree of completion of each field according to an index between $0 \%$ and $100 \%$.

\section{Results and discussion}

The current international case-study presents details of an assessment of management effectiveness within two Maltese wetlands, and extends the perspective of evaluation with respect to governance towards sustainability, linking evaluation with a gradation model of integrated management in the light of a conceptual perspective (Figure 5). It is safe to say that this comprehensive assessment exercise has been by far the most in-depth evaluation for Mediterranean PAs to date.

\subsection{Detailed profile according to sustainable development dimensions \& sustainable development principles}

The detailed profile of management effectiveness was created on the basis of an assessment of the SD principles, and may be described as a comprehensive assessment of evaluated PAs and their current policies by means of a range of indicators evaluated and described along a five-dimensions balanced scorecard (Figure 6). It was discovered in both PAs that there is no balanced

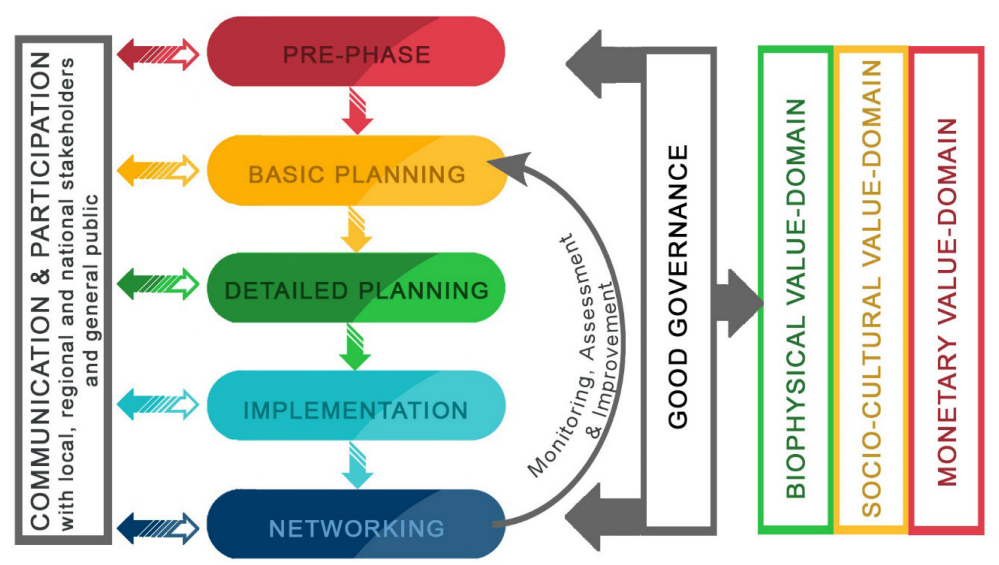

Figure 5. Gradation model of integrated protected area management and diagnostic of IPAM framework. The conceptual framework focusses on the interactive processes between social, cultural, ecological and economic subsystems. There are more specific components that are nested within the phases of each subsystem, but they are not shown here (source: authors' own draft)
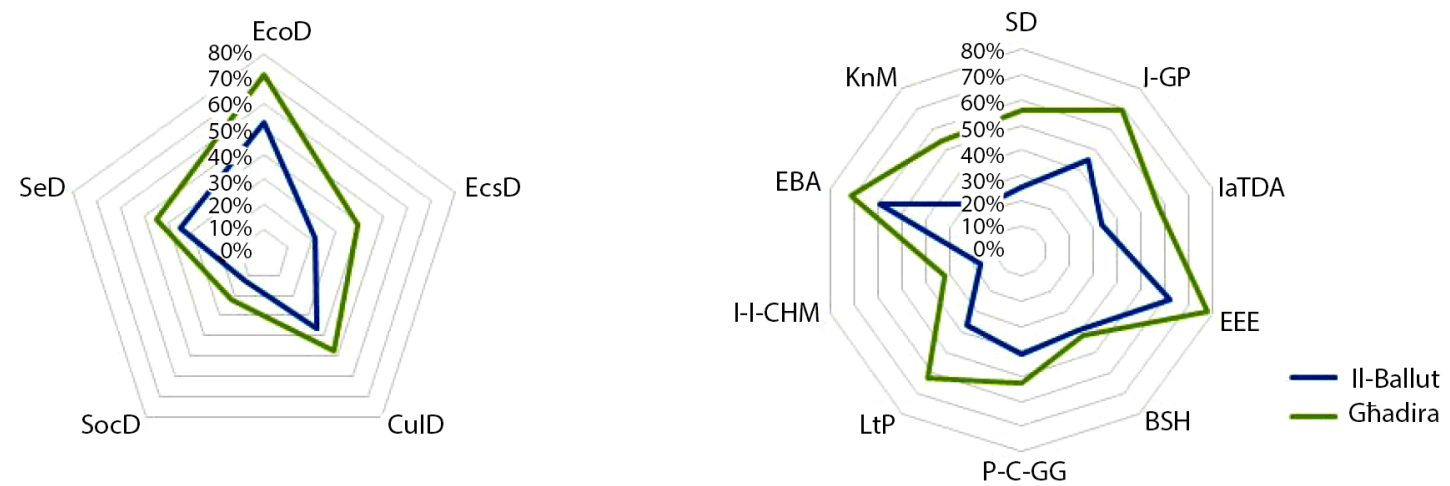

EcoD - Ecological Dimension; EcsD - Economics Dimension; CUID - Cultural Dimension; SocD - Dimension; SeD - Dimension; SD - Sustainable Development; I-GD Internationality, global perspective; IaTDA - Inter- and Transdisciplinary approaches; EEE - Ecological and economic effectiveness; BSH - Benefit-sharing; P-C-GG - Participanion, communication, good governance; LtP - Long-term perspective; I-I-CHM - Innovation, intervation and change management; EBA - Ethically based approach; $\mathrm{KnM}$ - Knowledge management

Figure 6. Summary of scorecard footprints of Il-Ballut and Ghadira management according to the sustainable development dimensions and ten sustainable development principles 
integration of each dimension (Figure 6) within the context of the complexity of integrated protected area management. The weaknesses are visible in the social and economic dimensions, and could lead to problems with optimising procedures, eliminating risks and conflicts and reducing duplication. There is an urgent need to improve the level of stakeholder participation and interest as the main part of the social dimension, and also the financial portfolio for PA management.

In particular, the following fields and projects of the Il-Ballut management are exceptional: a comprehensive, basic ecological inventory; high-quality and unique projects aimed at boosting ecological effectiveness (e.g. a project to conserve Malta's endemic killifish); systematic public relations work within and outside the region; qualified, motivated and effective team members and teamwork. On the other hand, we could identify the general absence of sufficient implementation of adaptive management and knowledge management. A possibility would be to incorporate the site within a nature trail with the aim of catalyzing and supporting more effective knowledge management and positive improvement of attitudes towards the environment on a local and national level.

\subsection{Detailed management effectiveness assessment of PA life-cycle}

Research has confirmed that IPAM can help managers in the challenging role of PA management, especially in identifying specific fields of activity (FoA) that need to be revised (Getzner et al., 2012; Jungmeier, 2014; Egner \& Jungmeier, 2014; Tomaskinova \& Tomaskin, 2018; Tomaškinová et al., 2019). Modern PA management must focus on the balanced development of all five dimensions, ten sustainable development principles and 29 FoA in the process of good governance. The index of completion showing total management effectiveness is of 0.388 in Il-Ballut and 0.588 in the more effectively managed but longer-established Ghadira (Figure 7).

The greatest weaknesses were noted in the detailed planning phase [in FoA-12: design of (regional) economic programmes] (Figures 8-9). In addition to the primary objective of protecting $\mathrm{BiDi}$, PAs should serve several purposes such as regional economic development, social inclusion and the sharing of benefits of protection. It is evident that well-managed PAs can be crucial in shaping and promoting large-scale developments and can also derive benefits from these developments. FoA-12 focusses upon the implementation and development of sustainable

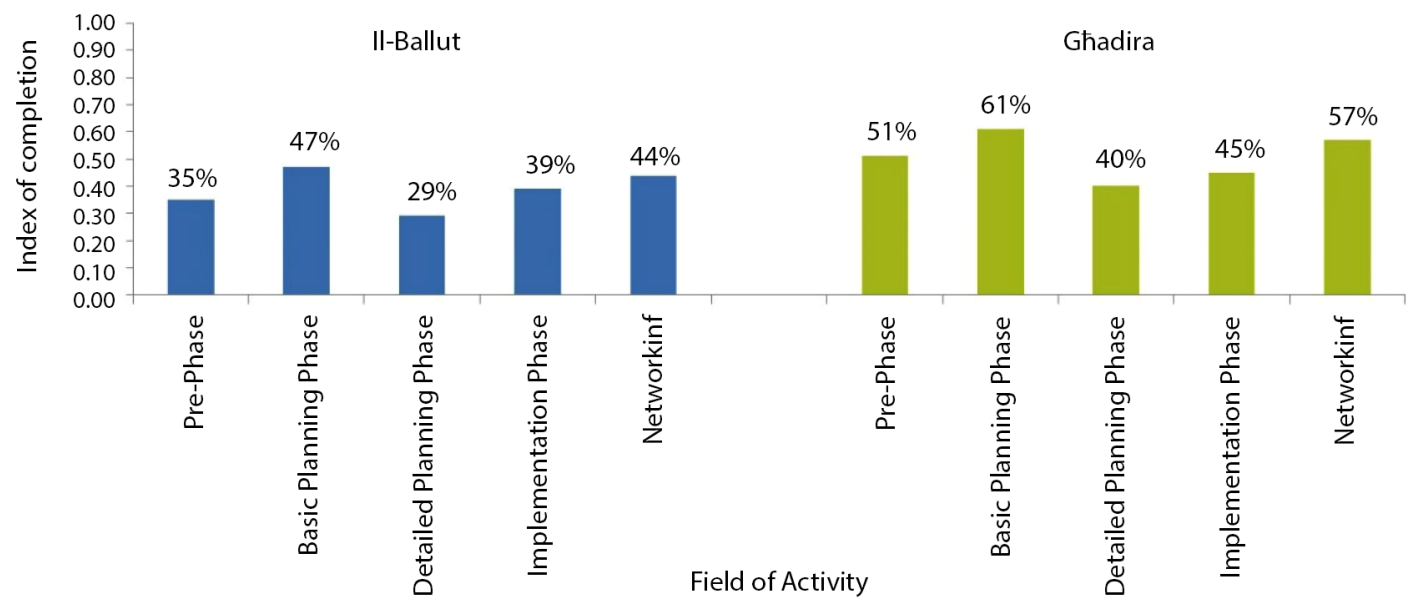

Figure 7. Comparison of management effectiveness of selected wetlands in each phase of the PA life-cycle

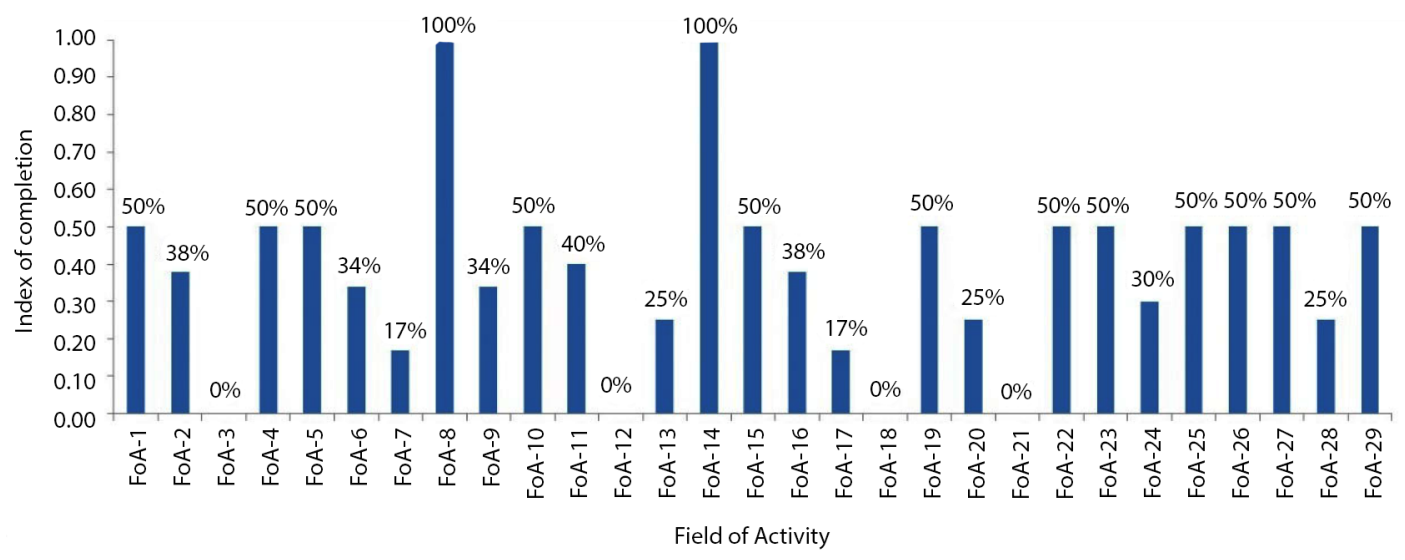

Figure 8. Detailed assessment of each field of activity in the life-cycle of Il-Ballut 


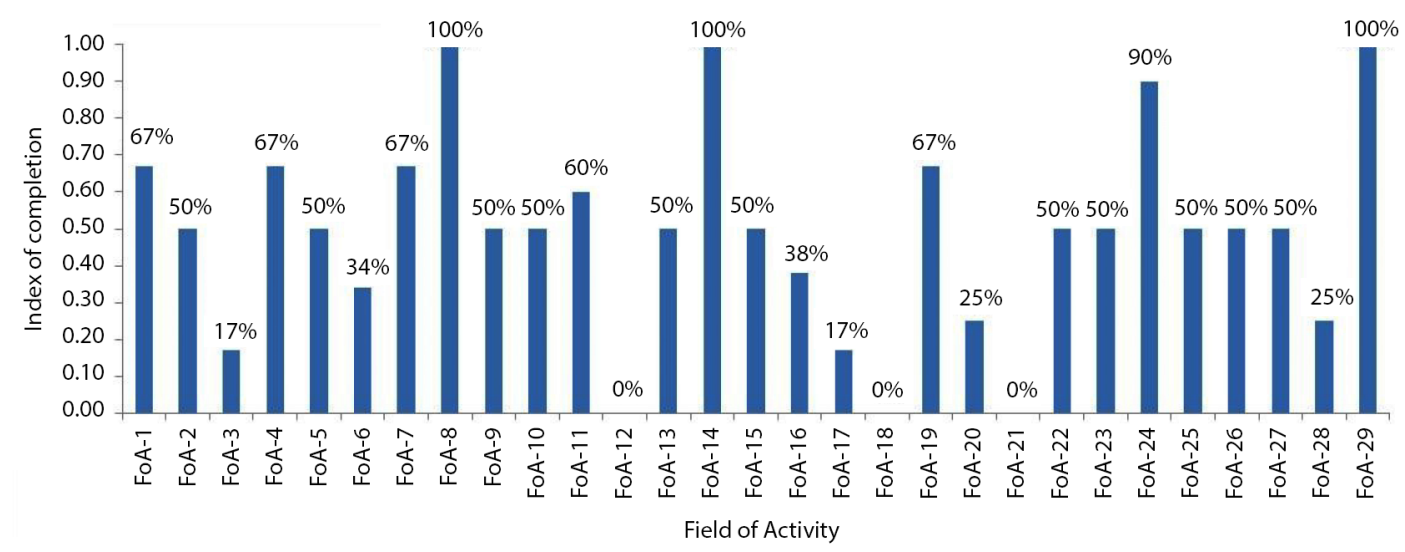

Figure 9. Detailed assessment of each field of activity in the life-cycle of Ghadira

economic structures while paying close attention to issues relating to PAs. As opposed to earlier attitudes, PAs are nowadays seen as an integrated, co-existing element of the economy, contributing considerable benefits to a region (Borrini-Feyerabend et al., 2013; Figgis et al., 2015; Jungmeier, 2014; Tomaškinová et al., 2019). Of course, these functions must be developed properly and undertaken as part of a participative process.

The detailed assessment of each of the FoAs throughout the life-cycle of both PAs (Figures 8-9) highlighted several critical fields of activity (Table 2), and reveals the broad tendency in management strategies and actions to give less than the deserved importance to most of the cross-cutting areas of activity. Hence, factors evidencing powerful links to the achievement of effective management outcomes, such as communication and participation, community involvement and programmes of community benefit, require timely efforts to improve efficiency.

Table 2. Critical fields of activity in life-cycle management

\begin{tabular}{|l|c|c|}
\hline \multicolumn{1}{|c|}{ Field of Activity } & \multicolumn{2}{c|}{$\begin{array}{c}\text { Index of } \\
\text { Importance }\end{array}$} \\
\cline { 2 - 4 } & Il-Ballut & Ghadira \\
\hline $\begin{array}{l}\text { FoA-3: Communication and } \\
\text { participation I }\end{array}$ & 1 & 0.83 \\
\hline FoA-7: Basic investigation & 0.83 & 0.33 \\
\hline $\begin{array}{l}\text { FoA-12: Design of (regional) economic } \\
\text { programmes }\end{array}$ & 1 & 1 \\
\hline $\begin{array}{l}\text { FoA-13: Specific Planning (Subsidiary } \\
\text { Plans) }\end{array}$ & 0.75 & 0.5 \\
\hline $\begin{array}{l}\text { FoA-17: Management assessment and } \\
\text { limitation }\end{array}$ & 0.83 & 0.83 \\
\hline $\begin{array}{l}\text { FoA-18: Data and information } \\
\text { management }\end{array}$ & 1 & 1 \\
\hline $\begin{array}{l}\text { FoA-20: Communication and } \\
\text { participation III }\end{array}$ & 0.75 & 0.75 \\
\hline $\begin{array}{l}\text { FoA-21: Development of protected area's } \\
\text { region }\end{array}$ & 1 & 1 \\
\hline FoA-28: Networking Social & 0.75 & 0.75 \\
\hline
\end{tabular}

Both PA management set-ups are also limited by lack of impact assessment and limitation of sources of funding. There is no developed assessment of management effectiveness and long-term perspectives based on participative processes. Above all, the management failed to take into account very important factors as indicators to evaluate success and necessary communication with strategic stakeholders.

\subsection{Addressed challenges and high-priority frame recommendations}

Based on comprehensive assessment of evaluated PAs management effectiveness, we have identified four main present challenges towards sustainability and good governance:

- Funding;

- Knowledge and information management (including scientific knowledge);

- Social learning;

- Communication and participation.

Public and private funding of the PAs (sponsoring, donations, other forms of private funding) needs to be bolstered, and more public support for conservation needs to be raised and harnessed [e.g. willingness-to-pay (WTP) for conservation based on preferences and perception use values (e.g. expenditure for travel, etc.) and non-use values (e.g. existence value of species and habitats]. It is clearly evident that the change in conceptions and SD principles within PA management has yet to be systematically assessed (Borrini-Feyerabend et al., 2013; Diaz et al., 2015; Dudley et al., 2017; Ervin et al., 2010; Figgis et al., 2015; Lordkipanidze et al., 2019), and is crucial to give priority to and execute policies which maximize the existing synergies (Pham-Truffert et al., 2020) between the SD dimensions and principles. The management of PAs is evolving and becoming more demanding and diverse (Appleton, 2016). In this setting, trans-disciplinary PA management effectiveness could well be of value as a means of keeping stakeholders informed and gathering tacit knowledge (Jungmeier, 2014; Getzner et al., 2012) besides being useful for the PA management authority as an 
information and management instrument. Besides, it also constitutes an addition to an expanding knowledge base (Gross et al., 2016) on the mission of PAs. Such methods and tools may hence also assist in the "good governance" of PAs, and be conducive to social learning experiences for all stakeholders. Some measure of general acceptance by stakeholders is therefore deemed to constitute an important element for effective IPAM. (Getzner et al., 2012). Jungmeier (2014) states that the times of sectorally educated self-taught persons involved in PA management are behind us; what is now required for the next decade is the recruitment and input of multifunctional PA managers coupled with new learning opportunities to acquire new skills. Irrespectively of their area of expertise, protected area practitioners ought to be considered as respected professionals with specific skills (Appleton, 2016; Worboys et al., 2015). There is a need for a worldwide improvement in the recognition of skilled jobs and occupations linked to protected areas since these are crucial to the longterm well-being of both nature and humanity (Danilina \& Kopylova, 2011). The personal and institutional enhancement of capacities is evidently of great importance. Effective networking offers a way of moving forward, based on applying best practices, learning and adapting (Gross et al., 2016). Multi-disciplinary networking is indispensable for social learning in PA management for augmenting flow and mutual learning, as well as for mainstream generation and dissemination of a wide range of knowledge (De Groot et al., 2010; Tomaškinová et al., 2019). Many different types of networking (networking ecological, economic and social) also create a positive environment for PA managers (Tomaskinova \& Tomaskin 2018; Tomaškinová et al., 2019) and give them a feeling of belonging to a professional community - a team of friends always there to assist and support each other, no matter the distances that separate them (Danilina \& Kopylova, 2011).
Protected area managers not only tend to characteristically view communication as being of lesser relevance, even when they would like to carry out such an exercise, but also tend to lack a satisfactory level of professional knowledge and experience (Getzner et al., 2012). They are hampered by two factors: a dearth of training opportunities on one hand, and a scarcity of PR professionals as opposed to biologists, ecologists et seq. (Jungmeier, 2014) - working in protected area management.

Against this background, more awareness-raising for protected area managers, as to the importance of communication, is indicated, and therefore also as to the necessity of both communication plans and comprehensive and systematic PR initiatives at and beyond the local and regional level. For such goals to be attained, PAs should take notes from the business sector and tackle the task accordingly. Experts will need to be hired from the economy, business development and public relations fields. Capacity-building measures must be undertaken; managers must actively collaborate with partners from other sectors, including communities, regional developers and the media. And finally, a well-thought-out and practicable communication strategy (Tomaskinova \& Tomaskin 2018; Tomaškinová et al., 2019), complete with aims and an action plan, would need to be fashioned to assist in pinpointing the main messages that the PA managers desire to put across.

De Groot et al. (2010), Figgis et al. (2015), Surkin (2011) and Erg et al. (2015) have proven that there is a very close link between sustainable development and good governance.

In this context, it is necessary to appeal for the required institutional changes in good governance at the government level.

Every definite challenge creates an opportunity. The assessment has highlighted the following actions that need high-priority concentration of resources (Table 3 ) in the

Table 3. Recommended actions with high priority

\begin{tabular}{|l|l|c|c|}
\hline \multicolumn{1}{|c|}{ Field of Activity } & \multicolumn{1}{|c|}{ Recommended Action } & Il-Ballut & Ghadira \\
\hline \multirow{4}{*}{ FoA-2: Feasibility Check } & Feasibility profile & $\checkmark$ & $\checkmark$ \\
\hline \multirow{2}{*}{$\begin{array}{l}\text { FoA-3, FoA-6: Communication and } \\
\text { participation I \& II }\end{array}$} & Toolkit early communication & $\checkmark$ & $\checkmark$ \\
\hline & Virtual communication backbone & $\checkmark$ & $\checkmark$ \\
\hline & Checklist transparency & $\checkmark$ \\
\hline & Capacity-building plans & $\checkmark$ & $\times$ \\
\hline FoA-7: Basic Investigation & Data research and operation & $\checkmark$ & $\times$ \\
\hline FoA-11: Ecosystem-based Management Plans & Priorities and measures & $\checkmark$ & $\checkmark$ \\
\hline \multirow{2}{*}{$\begin{array}{l}\text { FoA-12: Design of Regional Economic } \\
\text { Programmes }\end{array}$} & SWOT analysis & $\checkmark$ & $\checkmark$ \\
\hline & Long-term financial plans & $\checkmark$ & $\checkmark$ \\
\hline & Service Portfolio \& Platform & $\checkmark$ & $\checkmark$ \\
\hline FoA-13: Specific Planning (Subsidiary Plans) & Interface specific plans & $\checkmark$ & $\checkmark$ \\
\hline FoA-16: Financing (Business Plan) & List of benefits & $\checkmark$ & $\checkmark$ \\
\hline \multirow{2}{*}{$\begin{array}{l}\text { FoA-17: Management assessment and } \\
\text { limitation }\end{array}$} & Pre-check & $\checkmark$ & $\checkmark$ \\
\hline & Transparency & $\checkmark$ & $\checkmark$ \\
\hline & Monitoring plan development and implementation & $\checkmark$ & $\checkmark$ \\
\hline
\end{tabular}




\begin{tabular}{|c|c|c|c|}
\hline Field of Activity & Recommended Action & Il-Ballut & Ghadira \\
\hline \multirow{4}{*}{ FoA-18: Data and Information Management } & System design & $\checkmark$ & $\checkmark$ \\
\hline & Metadata catalogue & $\checkmark$ & $\checkmark$ \\
\hline & Data interfaces & $\checkmark$ & $\checkmark$ \\
\hline & Science and information assessment & $\checkmark$ & $\checkmark$ \\
\hline \multirow{3}{*}{ FoA-21: Development of PA's Region } & Regional Economic Programme & $\checkmark$ & $\checkmark$ \\
\hline & Info-platform & $\checkmark$ & $\checkmark$ \\
\hline & Partnership & $\checkmark$ & $\checkmark$ \\
\hline \multirow[t]{2}{*}{ FoA-24: Visitor Management \& Services } & $\begin{array}{l}\text { Nature-based tourism (visitors' infrastructure \& } \\
\text { facilities), education and information }\end{array}$ & $\checkmark$ & $x$ \\
\hline & Visitors' monitoring system & $\checkmark$ & $x$ \\
\hline \multirow{2}{*}{ FoA-28: Networking social } & Assessment of social qualification of staff & $\checkmark$ & $\checkmark$ \\
\hline & Training plans for site managers & $\checkmark$ & $\checkmark$ \\
\hline
\end{tabular}

Note: Symbols indicate: $\checkmark$ - high priority, $\mathbf{x}$ - normal priority.

Il-Ballut and Ghadira life-cycle, for the purpose of efficiency management improvement in critical FoAs.

The fulfilment of the specific objectives and targets of different categories of PAs, in order to secure and improve the conservation of $\mathrm{BiDi}$ as well as to facilitate participation and communications and gain the acceptance of various stakeholders and funding bodies (BorriniFeyerabend et al., 2013; Diaz et al., 2015; Lordkipanidze et al., 2019; Mayer et al., 2012; Stringer \& Paavola, 2013), poses a considerable but workable challenge. However, it requires high social capital in the individual management bodies of PAs (Jungmeier, 2014; Getzner et al., 2012) and complete implementation frameworks, and sufficient resources for funding efficient and effective protected area management bodies. Spiderweb diagrams are appropriate means to visualise the desired PA strategy according to the Ramsar Convention (Ramsar Convention, 2005; Ramsar Convention Secretariat, 2010a, 2010b; Ramsar Convention on Wetlands, 2018). Figure 10 shows the estimated significance of wetland management targets. These visualised objectives constitute the basis for more effective wetland management towards good governance.

Our research has shown that further studies are needed, especially so as to marshal public support for the conservation of both evaluated PAs, based on identifying its material and non-material benefits taking into

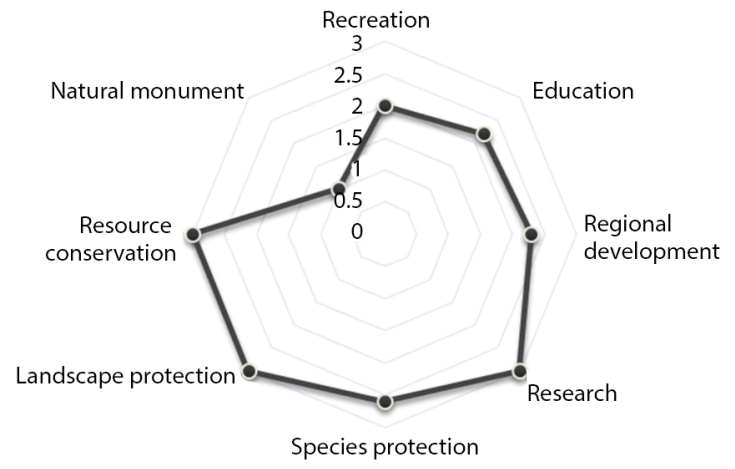

Figure 10. Spiderweb of functions in wetlands consideration the ecological, social, cultural, economic and safety aspects of the five dimensions model of SD. By means of the public exposition of such results, aimed particularly at regional communities and decision-makers, a common understanding of the integrated management process and a shift in attitude favouring the support of sustainable development within the PA can be brought about and used to maximum advantage.

\section{Conclusions}

PA management is a complex process in which various problems need to be analysed, discussed and solved. Our study indicates that both evaluated wetlands face new requirements for integrated planning and management. The evaluated Natura 2000 sites possess not only a highly valued environmental capital but also a great potential for knowledge management (including scientific knowledge) and educational visits and in fostering awareness on ecological communities and the general public. The development of PAs towards sustainability requires new qualities, improved concepts, and tools for new ways of planning, in the context of addressing present challenges for the next decade. Assessment is crucial for management, especially in today's world where rapid changes are experienced in the biophysical, socio-cultural and economics subsystems. PA management transformation requires a wide range of skills and knowledge (including specific expertise) from modern interdisciplinary managers to allow them to manage the complexity of PA systems in the Third Millennium and presents a challenge "How to manage PAs and consider them as opportunities to support SD" (e.g. what works and what does not work in the management process). Management effectiveness assessment is a vital component of a proactive style of PA management in the context of good governance. Through assessment - both positive and negative - opportunities for learning will arise, and continual improvement can be combined with the anticipation of future threats and opportunities. External evaluation is important and necessary since it assists 
the PA management team in addressing such sensitive and intractable subjects as the enhancement of the credibility of park management through limiting politicallymotivated decision-making, and also provides a solid basis for shifts in policy. However, for a successful exercise to be carried out, all the management officers have to be on board, since ultimately only they have the power and responsibility to implement any recommendations that may derive from the process.

\section{Author contributions}

Conceptualization, J.T. and J.Tom.; methodology, J.T.; validation, J.T., J.Tom., H.T., A.F.A.V. and V.A.; formal analysis, J.T.; investigation, J.T., J.Tom., H.T. and V.A.; writing - original draft preparation, J.T., J.Tom., H.T., A.F.A.V. and V.A.; writing - review and editing, J.T., J.Tom., H.T., A.F.A.V. and V.A.; visualization, J.T.; supervision, J.T.; project administration, J.T., J.Tom., H.T., A.F.A.V. and V.A.; funding acquisition, J.T. All authors have read and agreed to the published version of the manuscript.

\section{Acknowledgements}

Judita Tomaskinova acknowledges funding from the ReNature project. This project has received funding from the European Union's Horizon 2020 research and innovation programme under grant agreement No 809988. We would like to thank anonymous reviewers for input which has improved the manuscript.

\section{Conflicts of interest}

The authors declare that they have no conflict of interest.

\section{References}

Appleton, M. R. (2016). A global register of competences for protected area practitioners. IUCN.

Balzan, M. V., Caruana, J., \& Zammit, A. (2018). Assessing the capacity and flow of ecosystem services in multifunctional landscapes: Evidence of a rural-urban gradient in a Mediterranean small island state. Land Use Policy, 75, 711-725. https://doi.org/10.1016/j.landusepol.2017.08.025

Borrini-Feyerabend, G., Dudley, N., Jaeger, T., Lassen, B., Pathak Broome, N., Phillips, A., \& Sandwith, T. (2013). Governance of protected areas: From understanding to action. Best practice protected area guidelines series No. 20. IUCN.

Cirtina, D., \& Gamaneci, G. (2015). Study regarding the elaboration of certain management measures of the protected area Oltet Gorges, Gorj Country - a premise of the sustainable development. Journal of Environmental Protection and Ecology, 16(2), 667-675.

Cohen-Shacham, E., Walters, G., Janzen, C., \& Maginnis, S. (2016). Nature-based solutions to address global societal challenges. IUCN. https://doi.org/10.2305/IUCN.CH.2016.13.en

Convention on Biological Diversity. (2020). Aichi Biodiversity Targets. https://www.cbd.int/sp/targets/

Cramer, W., Guiot, J., Fader, M., Garrabou, J., Gattuso, J.-P., Iglesias, A., Lange, M. A., Lionello, P., Llsat, M. C., Paz, S., Peñuelas, J., Snoussi, M., Toreti, A., Tsimplis, M. N., \& Xo- plaki, E. (2018). Climate change and interconnected risks to sustainable development in the Mediterranean. Nature Climate Change, 8, 972-980.

https://doi.org/10.1038/s41558-018-0299-2

Danilina, N. R., \& Kopylova, S. L. (Eds.) (2011). Protected area staff training: Guidelines for planning and management. IUCN.

De Groot, R. S., Alkemade, R., Braat, L., Hein, L., \& Willemen, L. (2010). Challenges in integrating the concept of ecosystem services and values in landscape planning, management and decision-making. Ecological Complexity, 7(3), 260-272. https://doi.org/10.1016/j.ecocom.2009.10.006

Diaz, S., Demissew, S., Joly, C., Lonsdale, W. M., \& Larigauderie, A. (2015). A Rosetta Stone for nature's benefits to people. PLoS Biology, 13(1), e1002040.

https://doi.org/10.1371/journal.pbio.1002040

Dudley, N. (2013). Guidelines for applying protected area management categories. Best practice protected area guidelines series No. 21. IUCN.

Dudley, N., Ali, N., \& MacKinnon, K. (2017). Protected areas helping to meet the sustainable development goals. Parks, 23(2), 9-12.

https://doi.org/10.2305/IUCN.CH.2017.PARKS-23-2ND.en

Dudley, N., Burlando, C., Cooney, R., Jones, S., \& Kehaulani Watson, T. (2016). Draft principles for justice and equity in distribution of benefits from ecosystem services in protected areas. In C. Burlando, A. Te P. Mead, M. M. Noshirwani, C. Seagle, \& T. Kehaulani Watson (Eds.), Policy matters. Issue 20: From solutions to resolutions: A new social compact for just and effective conservation of biodiversity (pp. 41-54). CEESP, IUCN.

Energy \& Water Agency. (2020). Action C.13: Restoration of one of the coastal wetlands. https://www.rbmplife.org.mt/content/ restoration-one-coastal-wetlands

ERA. (2014a). Il-Ballut ta' Marsaxlokk: Natura 2000 Management Plan (SAC). Epsilon International SA - Adi Associates Environmental Consultants Ltd Consortium, Malta. https:// era.org.mt/wp-content/uploads/2019/05/Il-Maghluq_ta_Marsaskala_ManagementPlan.pdf

ERA. (2014b). L-Inћawi tal-Ghadira: Natura 2000 Management Plan (SAC). Epsilon International SA - Adi Associates Environmental Consultants Ltd Consortium, Malta. https://era. org.mt/wp-content/uploads/2019/05/L-Inhawi_tal-Ghadira_ ManagementPlan.pdf

ERA. (2018). Biodiversity. In State of the environment report 2018 (Reporting status from 2009 to 2015).

Erg, B., Groves, C., McKinney, M., Michel, T. R., Phillips, A., Schoon, M. L., Vasilijevic, M., \& Zunckel, K. (2015). Transboundary conservation: A systematic and integrated approach. In Best practice protected area guidelines series: No. 23. IUCN. https://doi.org/10.2305/IUCN.CH.2015.PAG.23.en

Ervin, J., Sekhran, N., Dinu, A., Gidda, S., Vergeichik, M., \& Mee, J. (2010). Protected areas for the $21^{\text {st }}$ century: Lessons from UNDP/GEF's portfolio. United Nations Development Programme and Convention on Biological Diversity.

European Environment Agency. (2008). Environmental signals 2000 (Environmental assessment report No 6).

https://www.eea.europa.eu/publications/92-9167-205-X

European Environment Agency. (2018). Natura 2000: Birds and Habitats Directives. Malta. https://www.eea.europa.eu/ data-and-maps/figures/natura-2000-birds-and-habitat-directives-10/malta

European Environment Agency. (2020a). N2K MT0000014 dataforms. https://natura2000.eea.europa.eu/Natura2000/SDF. aspx ?site $=$ MT0000014 
European Environment Agency. (2020b). N2K MT0000015 dataforms. https://eunis.eea.europa.eu/sites/MT0000015

European Environment Agency. (2020c). Site factsheet for IlBallut ta' Marsaxlokk. EUNIS. https://eunis.eea.europa.eu/ sites/MT0000014

Eurostat. (2020). First population estimates: EU population up to nearly 513 million on 1 January 2018. https://ec.europa.eu/ eurostat/documents/2995521/9063738/3-10072018-BP-EN. pdf/ccdfc838-d909-4fd8-b3f9-db0d65ea457f

Figgis, P., Mackey, B., Fitzsimons, J., Irving, J., \& Clarke, P. (Eds.). (2015). Valuing nature: Protected areas and ecosystem services. Australian Committee for IUCN. https://www.academia. edu/20237661/Valuing_Nature_Protected_Areas_and_Ecosystem_Services

Forzieri, G., Cescatti, A., Silva, F. B., \& Feyen, L. (2017). Increasing risk over time of weather-related hazards to the European population: A data-driven prognostic study. The Lancet Planetary Health, 1(5), e200-e208.

https://doi.org/10.1016/S2542-5196(17)30082-7

Geijzendorffer, I. R., Beltrame, C., Chazee, L., Gaget, E., Galewski, T., Guelmami, A., Perennou, C., Popoff, N., Guerra, C. A., Leberger, R., Jalbert, J., \& Grillas, P. (2019). A more effective Ramsar Convention for the conservation of Mediterranean wetlands. Frontiers in Ecology and Evolution, 7(21), 1-6. https://doi.org/10.3389/fevo.2019.00021

Getzner, M., Jungmeier, M., \& Pfleger, B. (2012). Evaluating management effectiveness of national parks as a contribution to good governance and social learning. In B. Sladonija (Ed.), Protected area management (pp. 129-148). IntechOpen. https://doi.org/10.5772/50092

Gokce, D. (2019). Introductory chapter: Wetland importance and management. In D. Gokce (Ed.), Wetlands management - Assessing risk and sustainable solutions (pp. 3-10). IntechOpen.

Golumbeanu, M., Spinu, A. D., Zaharia, T., Mateescu, R., Nenciu, M. I., Enciu, E., Vlasceanu, L., Alexandrov, L., \& Costache, M. (2019). Coastal sustainability indicators for the Romania Black Sea coast. Journal of Environmental Protection and Ecology, 20(4), 1831-1841.

Gross, J. E., Woodley, S., Welling, L. A., \& Watson, J. E. M. (Eds.) (2016). Best practice protected area guidelines series. No. 24 : Adapting to climate change: Guidance for protected area managers and planners. IUCN.

https://doi.org/10.2305/IUCN.CH.2017.PAG.24.en

IUCN. (2020a). IUCN Green list of protected and conserved areas: The global standards for protected areas in the $21^{\text {st }}$ century. https://iucn.my.salesforce.com/sfc/p/\#24000000e5iR/ a/1o0000005kM6/tFf7d8BgjDRxUKyujmm7DdgrfPz77RzGkQizYNb_dmA

IUCN. (2020b). The promise of Sydney. In IUCN World Parks Congress. IUCN.

https://www.iucn.org/theme/protected-areas/about/promisesydney

Jungmeier, M. (2014). In transit towards a third generation of protected areas? Concepts, principles and activities in the integrated management of protected areas. International Journal of Sustainable Society, 6(1/2), 1-17. https://doi.org/10.1504/IJSSOC.2014.057889

Egner, H., \& Jungmeier, M. (Eds.). (2014). Parks 3.0 - Protected areas for a next society. Verlag Johannes Heyn.

Lordkipanidze, M., Bressers, H., \& Lulofs, K. (2019). Governance assessment of a protected area: The case of the Alde Feanen National Park. Journal of Environmental Planning and Management, 62(4), 647-670.

https://doi.org/10.1080/09640568.2018.1441014
Malta Environment and Planning Authority. (2014). Fifth national report on the implementation of the convention on biological diversity. https://www.cbd.int/doc/world/mt/mt-nr-05-en.pdf

Mayer, R., Plank, C., Plank, B., Bohner, A., Sărăţeanu, V., Samfira, I., Moisuc, A., Kirchmeir, H., Köstl, T., Zak, D., Árgay, Z., Dósa, H., Gazda, A., Balczó, B., Greguss, D., Bakó, B., Schmidt, A., Szinai, P., Petróczi, I., Sallai, R. B., Fábián, Z., Kreiner, D., Sterl, P., Costa, M., Gavrilovic, R., Randjic, D., Bîscă, V., Ivanov, G., \& Başcău, F. (2012). BE-NATUR: Transnational management of Natura 2000 sites. In B. Sladonija (Ed.), Protected area management. IntechOpen.

https://doi.org/10.5772/50653

Mediterranean Wetlands Initiative. (2018). Mediterranean Wetland Outlook 2: Solutions for sustainable Mediterranean Wetlands. Tour Du Valat.

https://medwet.org/publications/med-wetlands-outlook-2-2018/

Mittermeier, R. A., Turner, W. R., Larsen, F. W., Brooks, T. M., \& Gascon, C. (2011). Global biodiversity conservation: The critical role of hotspots. In F. E. Zachos \& J. C. Habel (Eds.), Biodiversity hotspots (pp. 3-22). Springer.

https://doi.org/10.1007/978-3-642-20992-5_1

Nature Trust - FEE Malta. (2020). Island wetlands of Malta. https://www.maltawetlands.org/general/search.php?lang=en \&protection[]=International\&order=island

Pham-Truffert, M., Metz, F., Fischer, M., Rueff, H., \& Messerli, P. (2020) Interactions among Sustainable Development Goals: Knowledge for identifying multipliers and virtuous cycles. Sustainable Development, 28(5), 1236-1250.

https://doi.org/10.1002/sd.2073

Ramírez, F., Rodríguez, C., Seoane, J., Figuerola, J., \& Bustamante, J. (2018). How will climate change affect endangered Mediterranean waterbirds? PLoS ONE, 13(2), e0192702. https://doi.org/10.1371/journal.pone.0192702

Ramsar Convention on Wetlands. (2018). Global Wetland Outlook: State of the world's wetlands and their services to people 2018. Ramsar Convention Secretariat.

Ramsar Convention Secretariat. (2010a). Designating Ramsar Sites: Strategic framework and guidelines for the future development of the List of Wetlands of International Importance. Ramsar handbooks for the wise use of wetlands ( $4^{\text {th }}$ ed., vol. 17). Ramsar Convention Secretariat.

Ramsar Convention Secretariat. (2010b). International cooperation: Guidelines and other support for international cooperation under the Ramsar Convention on wetlands. Ramsar handbooks for the wise use of wetlands ( $4^{\text {th }}$ ed., vol. 20). Ramsar Convention Secretariat.

Ramsar Convention. (2005, November 8-15). Resolution IX.1 Annex A: A conceptual framework for the wise use of wetlands and the maintenance of their ecological character. In 9th Meeting of the Conference of the Parties to the Convention on Wetlands (Ramsar, Iran, 1971), 8-15 November 2005, Kampala, Uganda.

Ramsar Sites Information Service. (2020). Annotated list of wetlands of international importance Malta. https://rsis.ramsar. org/sites/default/files/rsiswp_search/exports/Ramsar-Sitesannotated-summary-Malta.pdf?1533563602

Smardon, R. (2015). International wetlands policy and management issues. National Wetlands Newsletter, 37(3), 10-16.

Stringer, L., \& Paavola, J. (2013). Participation in environmental conservation and protected area management in Romania: A review of three case studies. Environmental Conservation, 40(2), 138-146. https://doi.org/10.1017/S0376892913000039

Surkin, J. (2011). Natural resource governance, empowerment and poverty reduction: Learning from practice. IUCN. 
Tomaskinova, J., \& Tomaskin, J. (2018). Life-cycle assessment of the Nature and History Park Il-Majjistral (Malta, EU). Journal of Environmental Protection and Ecology, 19(1), 236-243.

Tomaškinová, J., Tomaškin, J., \& Soporská, P. (2019). Ecosystem services and recreational values as building blocks for eco development in NATURA 2000 sites. Polish Journal of Environmental Studies, 28(3), 1925-1932.

https://doi.org/10.15244/pjoes/90623

Tour Du Valat. (2020). Our activity report just came out. https://tourduvalat.org/en/publications-en/our-activity-report-just-came-out/

UNEP-WCMC. (2020a). Global Partnership on Aichi Target 11. https://www.protectedplanet.net/target-11-dashboard

UNEP-WCMC. (2020b, July 31). Global database on protected areas management effectiveness. UNEP, IUCN. https://pame.protectedplanet.net/

Woodley, S., Bertzky, B., Crawhall, N., Dudley, N., Londono, J. M., MacKinnon, K., Redford, K., \& Sandwith, T. (2012). Meeting Aichi Target 11: What does success looks like for protected area systems? Parks, 18(1), 23-36.
Worboys, G. L., Lockwood, M., Kothari, A., Feary, S., \& Pulsford, I. (Eds.) (2015). Protected area governance and management. ANU Press. https://doi.org/10.26530/OAPEN_569111

World Bank. (2020a). World Development Indicators: Population density. https://databank.worldbank.org/source/world-development-indicators

World Bank. (2020b). Terrestrial protected areas (\% of total land area) - Malta. https://data.worldbank.org/indicator/ER.LND. PTLD.ZS?locations=MT

Young, J. C., Thompson, D. B. A., Moore, P., MacGugan, A., Watt, A., \& Redpath, S. M. (2016). A conflict management tool for conservation agencies. Journal of Applied Ecology, 53(3), 705-711. https://doi.org/10.1111/1365-2664.12612

Zawilińska, B. (2020). Residents' attitudes towards a national park under conditions of suburbanisation and tourism pressure: A case study of Ojców National Park (Poland). European Countryside, 12(1), 119-137.

https://doi.org/10.2478/euco-2020-0007 